\title{
Acute paraplegia resulting from haemorrhage into a spinal neurofibroma
}

\author{
Shih-Tseng Lee, MD, Tai-Ngar Lui, MD \\ Division of Neurosurgery, Department of Surgery, Chang Gung Medical College, Taipei, \\ Taiwan.
}

Acute paraplegia due to the intratumour haemorrhage of a spinal neurofibroma is a rare condition. We describe 2 patients with this unusual presentation. Surgical treatment was successful in both patients. These 2 cases are reported, and the literature is reviewed.

Key words: paraplegia; spinal tumour; neurofibroma; tumour haemorrhage.

\section{Introduction}

Acute paraplegia due to tumour bleeding in intraspinal neurofibroma is a rather rare phenomenon.

From 1978 to 1987 , a total of 227 cases of intraspinal tumour were treated in our department. Two of these had acute paraplegia due to intradural extramedullary tumours which later proved both grossly and histologically to be intraspinal neurofibroma with intratumour haemorrhage.

\section{Case reports}

\section{Case I}

This 48 year old male presented with a 10 month history of backache. Two days before admission, there was a sudden onset of paraplegia including urinary incontinence. Examination on admission revealed complete paraplegia with a sensory level at T10, markedly increased knee jerks and bilateral ankle clonus. Anal tone was tight. Spinal CSF was obtained before proceeding with the myelogram: it was xanthochromic and contained 306 red blood cell/cumm.; protein of $308 \mathrm{mg} / \mathrm{dl}$; and the glucose was $78 \mathrm{mg} / \mathrm{dl}$. The myelogram showed a concave complete block at T11 level, with the spinal cord displaced to the right, by an intradural extramedullary mass (Fig 1). On 16 August

Correspondence: Department of Surgery, Taipei Municipal Chung Shiao Hospital, 87 Tung-Teh Road, Nankang Taipei, Taiwan, 11502 ROC.
1978 a T8-T11 laminectomy was performed, and a yellowish, firm $2.2 \times 1.4 \times$ $0.8 \mathrm{~cm}$ tumour was found, originating from the left T10 posterior nerve root. It was totally removed. Pathological examination showed grossly a well encapsulated tumour with focal haemorrhage. Microscopically, it was a typical neurofibroma with focal haemorrhage (Fig 2). During the next several days there was some improvement of power in the lower extremities. Six months after discharge he still had a mild spastic gait, but muscle strength had improved to normal and there was no sensory or sphincter dysfunction.

\section{Case 2}

This 62 year old male presented with a 2 year history of low backache. The day prior to admission he had an acute onset of lower limb weakness, numbness, inability to walk and urinary retention. Examination on admission showed marked weakness (grade 1) in all muscle groups of both lower extremities. Pinprick, touch, temperature and vibration sensation were reduced below L1. The knee and ankle reflexes were absent. The anal sphincter was lax. Lumbar cerebrospinal fluid was xanthochromic and contained 223 red blood cells/cumm; the protein was $250 \mathrm{ml} / \mathrm{dl}$; and the glucose was $82 \mathrm{mg} / \mathrm{dl}$. Myelography revealed a concave complete block at L1 (Fig 3). On 18 November 1986 a T11-L2 laminectomy was performed, and a $4 \times 2 \times 1.5 \mathrm{~cm}$ yellowish firm intradural tumour was found at 


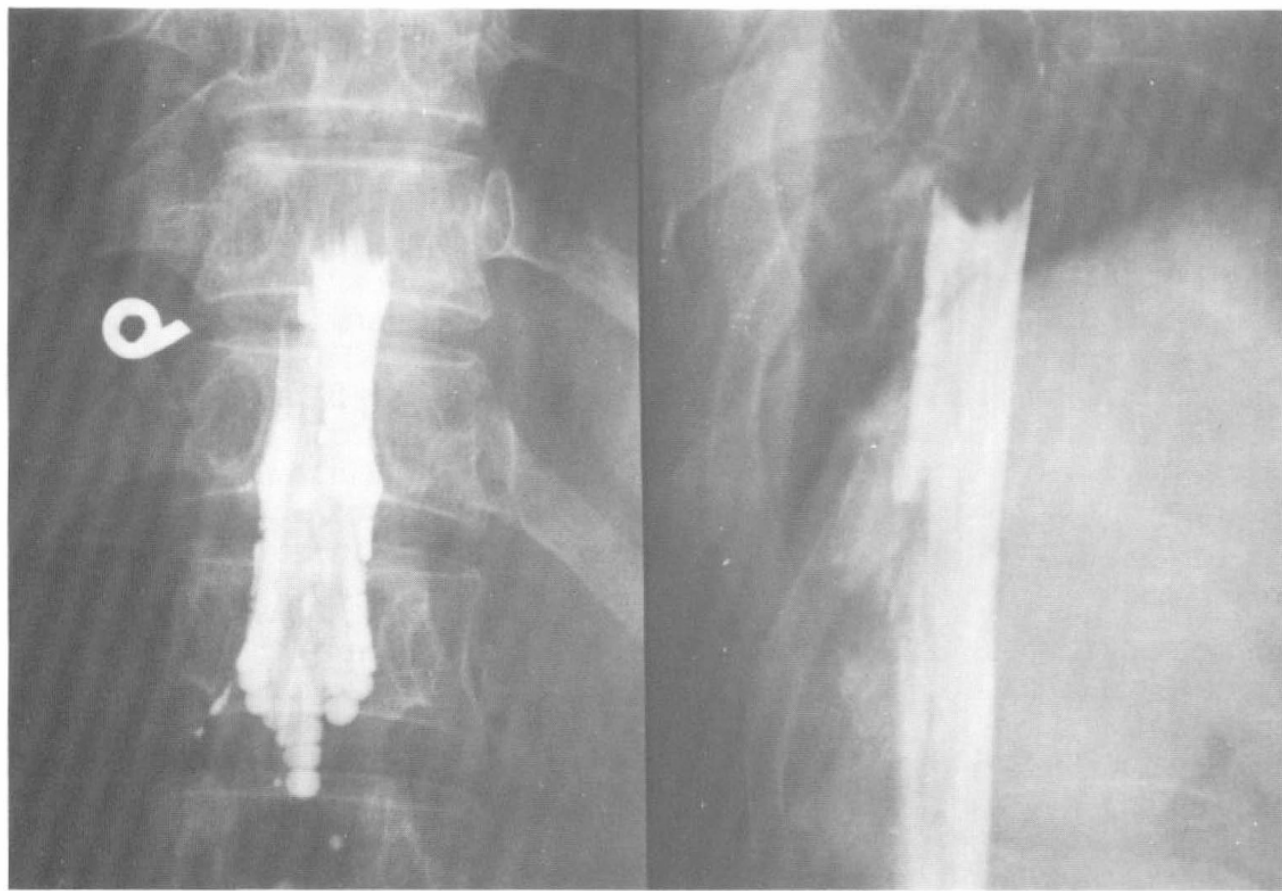

Figure 1 Myelogram in case 1: complete block at T10 due to intradural extramedullary lesion.

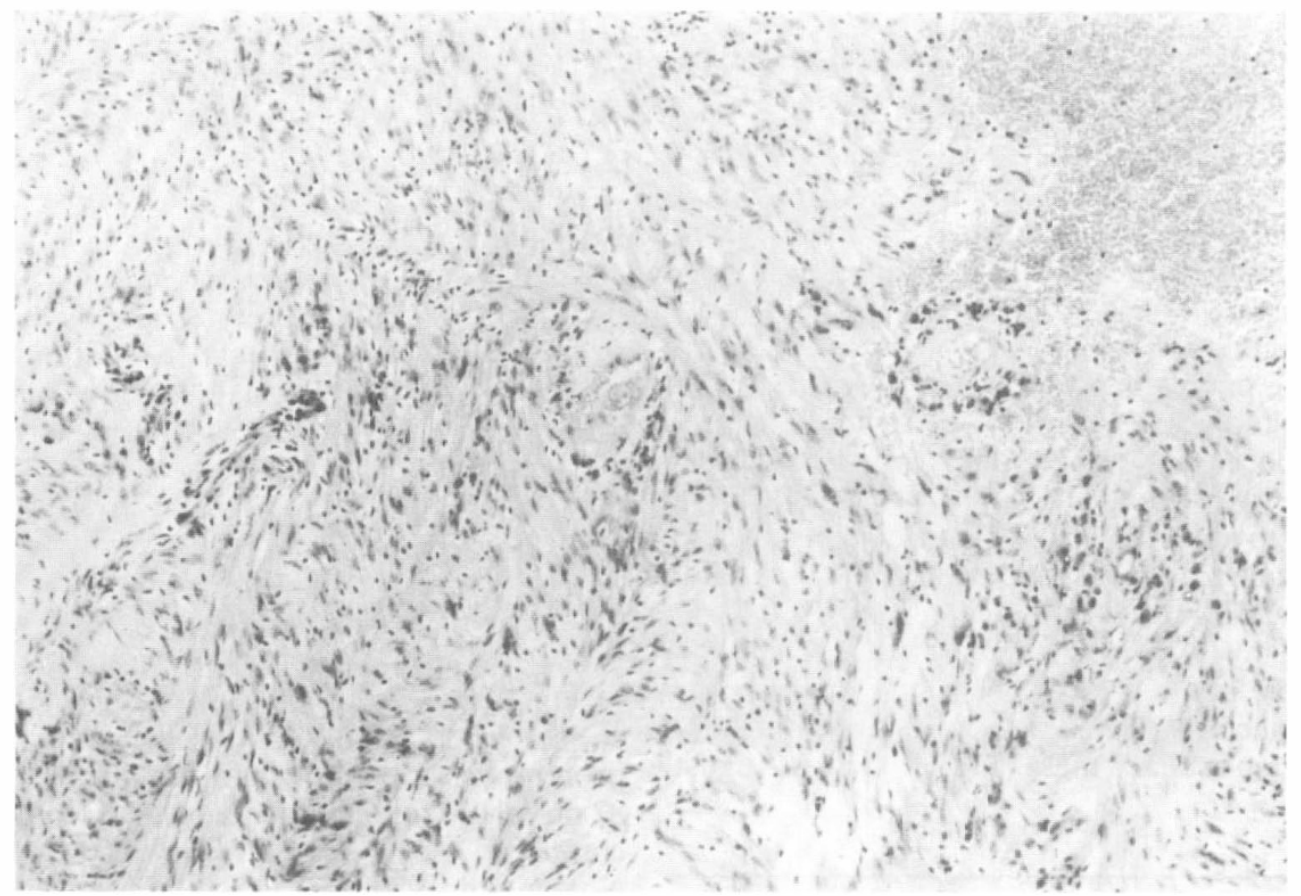

Figure 2 Photomicrograph of the tumour reveals neurofibroma with numerous dilated vessels and extravasation of the RBC (right corner) $(\mathrm{HE} \times 142)$. 


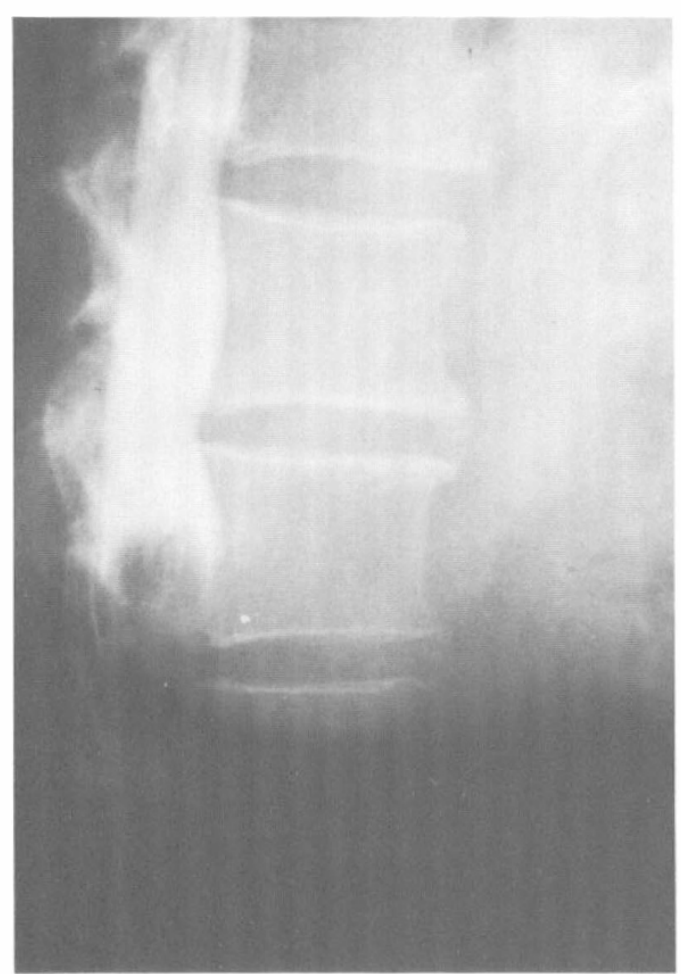

Figure 3 Myelogram in case 2: block at L1 due to an intradural lesion.

T12-L1 level. It originated from the right L1 root. The cauda equina was displaced to the left. The tumour was opened and yellowish fluid with a semiliquified hematoma was found. The tumour was totally excised. Microscopic examination showed a typical variably cellular neurofibroma and haemorrhage was apparent (Fig 4). One month later the patient resumed his former activities, being neurologically normal apart from persistent numbness in the right L1 dermatome.

\section{Discussion}

The commonest spinal intradural extramedullary tumour is the neurofibroma (schwannoma) which comprises approximately $30 \%$ of intraspinal tumours. Chemically, patients with an intraspinal neurofibroma have a slow progressive course and, irrespective of the location of the tumours, symptoms precede diagnosis by an average of 2 years. $^{1}$

Russel and Rubinstein describe the microscopic findings of spinal neurofibroma as often showing sinusoid dilatation of the blood vessels with hyaline thickening of their walls. These vessels are prone to spontaneous thrombosis resulting in areas of necrosis. Haemorrhage often occurs in the adjacent tissue. Tissue hemosiderin-laden macrophages are frequently encountered. ${ }^{2}$ Although microscopic bleeding is common in intraspinal neurofibroma, it is seldom clinically significant.

The clinical picture depends on the extent of the haemorrhage. When the haemorrhage is near the capsule, blood may enter the subarachnoid space. According to the literature, 13 cases of intraspinal neurofibroma with subarachnoid haemorrhage have been reported. ${ }^{3-14}$ In these patients the neurological features related to the tumour per se, before the development of subarachnoid haemorrhage. Because of this, the origin of the subarachnoid haemorrhage was misinterpreted, being considered to be of intracranial origin, and cerebral angiography was performed. ${ }^{5,6}$ If the intraspinal tumour is not diagnosed and treated after the first episode of subarachnoid haemorrhage, repeated bleeding from the tumour can occur. $3,5,7-10$

The tumour may enlarge with the abrupt occurrence of massive bleeding into it and cause acute paraplegia, as happened in the case reported by Krayenbuhl ${ }^{11}$ and as occurred in our patients. Previous reports suggested that physical exertion might induce tumour bleeding in the area of the conus medullaries or cauda equina. ${ }^{6.14} \mathrm{We}$ did not find this in our patients.

In conclusion, when a patient develops acute paraplegia from an intraspinal lesion, it is wise to consider a neurofibroma with intratumour haemorrhage in the differential diagnosis. Surgical intervention can be beneficial even for patients who have developed paraplegia.

\section{Acknowledgements}

The authors thank Miss Judy Perry for review and suggestions and Miss Yun Shu for secretarial assistance. 


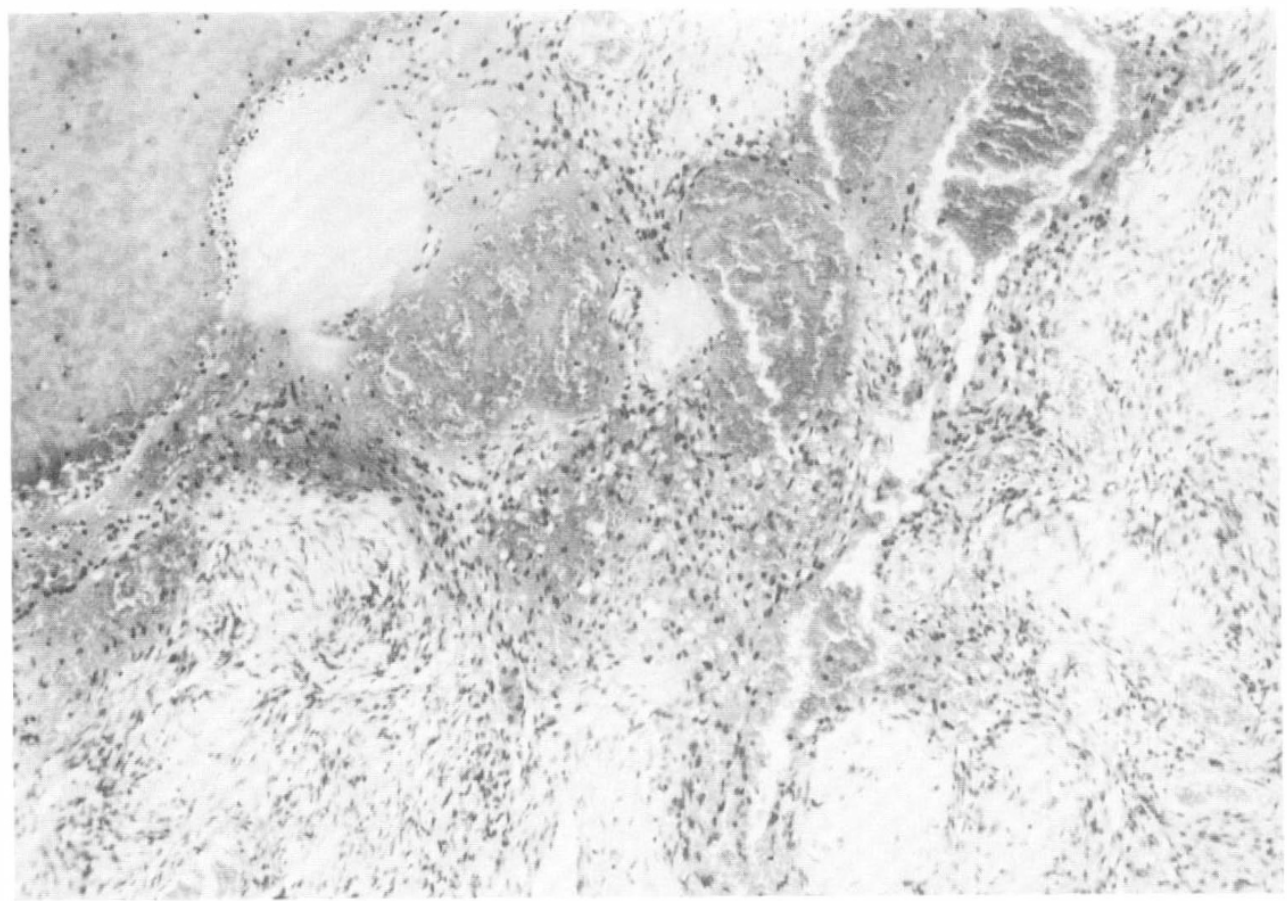

Figure 4 Photomicrograph shows extensive immature organised blood clots embedded in hyaline sclerotic neurofibroma cells $(\mathrm{HE} \times 142)$.

\section{References}

1 Stein BM (1985) Spinal intradural tumors, In: Wilkins RH, Rengachary SS, editors. Neurosurgery, vol 1. McGraw-Hill Company, New York: 1048-1061.

2 Russell DS, Rubinstein LT (1989) Tumors of nerve roots and peripheral nerves: In: Russell DS, Rubinstein LJ, editors. Pathology of Tumors of Nervous System. 4th ed. Williams and Wilkins, Baltimore: 372-401.

3 Andre-Thomas F, Scaeffer H, De Martel T (1930) Syndrome d'hemorragie meningee realisé par une tumeur de la queue de cheval. Paris Med 77: 292-296.

4 Bernell WR, Kepes JJ, Clough CA (1973) Subarachnoid hemorrhage from malignant schwannoma of the cauda equina. Tex Med 69: 101-104.

5 Djindjian M, Djindjian R, Hurth M, Lougnon J, Houdart R (1978) Les hemorragies meningees spinales tumorales: à propos de 5 cas arteriographies. Rev Neurol 134: 685-692.

6 De Divitiis E, Maiuri F, Corriero G, Donzelli R (1985) Subarachnoid hemorrhage due to a spinal neurinoma. Surg Neurol 24: 187-190.

7 Fincher EF (1951) Spontaneous subarachnoid hemorrhage in intradural tumors of the lumbar sac. $J$ Neurosurg 8: 576-584.

8 Fortuna A, La Torre E (1968) Neurinoma della cauda son emorrhagia subarachnoida circoscritta. Lab Neuro-psychiat 43: 1157-1164.

9 Grollmus J (1975) Spinal subarachnoid hemorrhage with schwannoma. Acta Neurochir (Wien) 31: 253-256.

10 Halpern J, Feldman S, Peyser E (1958) Subarachnoid hemorrhage with papilledema due to spinal neurofibroma. Arch Neurol Psychiat 79: 138-141.

11 Krayenbuhl H (1947) Spontane spinale subarachnoidalblutung und akute Ruckenmarkskompression bei intraduralem, spinalem neurinom. Schweiz Med Wochenschr 77: 692-694.

12 Motomochi M (1981) Spinal subarachnoid hemorrhage due to a thoracic neurinoma during anticoagulant therapy. A case report. Neurol Med Chir (Tokyo) 21: 781-784.

13 Muhtaroglu U, Strenge H (1980) Rezidivierende Subarachnoidalblutung bei spinalem Neurinom. Neurochirurgia (Stuttgart) 23: 151-155.

14 Prieto A, Cantu RC (1967) Spinal subarachnoid hemorrhage associated with neurofibroma of the cauda equina. J Neurosurg 27: 63-69. 